\title{
RADIOCARBON DATES FROM THE ICE-FREE CORRIDOR
}

\author{
Thomas G Arnold \\ Department of Archaeology, Simon Fraser University, Burnaby, BC, Canada V5A-1S6. Email: tarnold@ sympatico.ca.
}

\begin{abstract}
The Ice-Free Corridor has been hypothesized as the main migration route into the Americas since the 1930s. Radiocarbon dates have been used by archaeology, geology, and palynology to date the corridor. A total of $564{ }^{14} \mathrm{C}$ dates ranging between 20,000 and $8000 \mathrm{BP}$ from the corridor area were gleaned from the published literature. After assessing these dates for suitability, 255 were plotted over four time periods. The results indicate that the corridor was not feasible as an early human migration route until after 11,000 BP, or after the appearance of Clovis south of the continental glaciers.
\end{abstract}

\section{INTRODUCTION}

The hypothesized Ice-Free Corridor has provided archaeology with a convenient explanation to account for the initial colonization of the Americas south of the Late Wisconsin ice sheets. Defined as an unglaciated area along the eastern slopes of the Rocky Mountains between the westward advancing Laurentide ice sheet and the eastward flowing Cordilleran and mountain glaciers (Figure 1), it was first proposed by Johnson (1933:22) to account for the then recently discovered Folsom points.

Debate over whether it was a deglaciation or a glacial maximum corridor has continued over the decades with an entire issue of Quaternary International (Volume 32; Mandryk and Rutter 1996) dedicated to this discussion (the following list of publications provides an introduction to the literature on the Ice-Free Corridor and should not be considered exhaustive: Antevs 1934; Bryan 1969; Reeves 1973; Fladmark 1979; Rutter 1980; Holloway et al. 1981; Hickman et al. 1983; Jackson 1983; White and Mathewes 1986; Schweger and Hickman 1989; Bobrowsky and Rutter 1992; Mandyrk 1992; Meltzer 1993; Beaudoin et al. 1996; Burns 1996; Catto et al. 1996; Levson and Rutter 1996; Mandryk 1996; Wilson 1996; Driver 1998; Schwegar 1989b). Mandryk (1992:20-53) provides a chronology of the debate. To summarize briefly, prior to the advent of radiocarbon dating, the last glacial maximum was estimated to have occurred about 25,000 years ago (Johnson 1933:24; Antevs 1935:304,306,307) with the formation of the corridor occurring sometime between 20,000 and 15,000 years ago. Despite the lack of archaeological evidence at this time for Clovis or Folsom age sites in Alaska or northeast Asia, the corridor was seen as the route of entry for Palaeoindian cultures south of the glacial ice. ${ }^{14} \mathrm{C}$ dating revised these interpretations by showing that Clovis, Folsom, and the Late Wisconsin glaciation were more recent than previously assumed. According to Mandryk (1992:31-2), because archaeology was unwilling to accept a Mid-Wisconsin human entry into the New World, archaeologists redefined Johnson's deglaciation corridor as a glacial maximum corridor. Mandryk (1992:38) characterizes post-1960s corridor research as continuing to focus on the physical existence and timing of the corridor, with less debate on its environment.

This paper re-evaluates the ${ }^{14} \mathrm{C}$ dates from the corridor, what they suggest about the timing of its appearance and the potential role of the corridor in the settlement of the Americas.

\section{METHOD}

The study area is shown in Figure 2 with its western limits defined by the Rocky Mountain Trench extending north from the Canada/United States border along the Columbia, Fraser, and Kenchika river valleys in British Columbia. This western limit is extended in the Yukon Territory along the Liard, Frances, and Pelley river valleys and follows the Yukon River to the Alaska/Yukon border where it proceeds north along the border to the Beaufort Sea. The northern limit is the northern coast 
Canada (and immediate offshore islands) east from the Alaska/Yukon border to its intersection with the eastern limit in Queen Maude Gulf. The eastern limit begins with the political boundary between the Canadian provinces of Manitoba and Saskatchewan and extends north from the 60th parallel to Queen Maude Gulf. The southern limit of the study area runs along the Canada/United States border. This study area covers the eastern slopes of the Rocky Mountains, the potential northern staging area in the present-day Yukon and the southern outlet area in southern Alberta, Canada. ${ }^{14} \mathrm{C}$ dates from within this study area and bracketed between 20,000 and 8000 BP were collected from a variety of published sources including journals, books, dissertations, theses, and databases. A total of $574{ }^{14} \mathrm{C}$ dates from 343 separate sites were gleamed from the published literature.

Assessing these ${ }^{14} \mathrm{C}$ dates follows Nelson (1998). These dates were assessed based on the ${ }^{14} \mathrm{C}$ event of the sample dated, the samples relationship to its stratigraphic provenance, and whether it conformed to a standard ${ }^{14} \mathrm{C}$ date as defined by Stuiver and Polach (1977:356). This process reduced the original 574 dates to 255 dates from 164 locations. Figures 3A and 3B display the distributions of

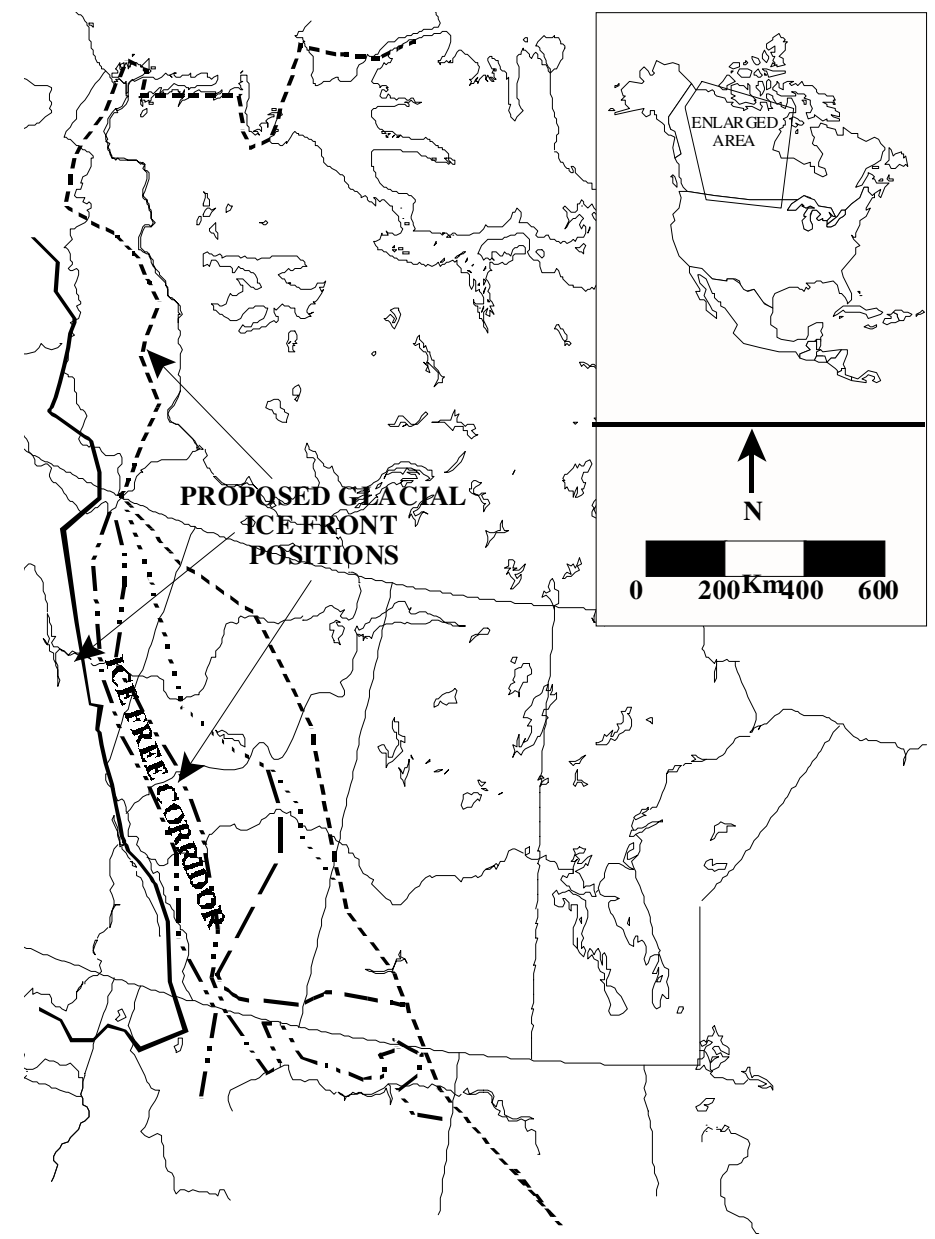

Figure 1 Traditional view of the Ice-Free Corridor (after Reeves 1973) 
dated locations before and after assessment. The reasons for rejected dated samples being eliminated from the study were:

1. The ${ }^{14} \mathrm{C}$ event could not be identified or was known to provide unreliable dates (e.g., freshwater shell, plants or lake sediment samples are known to be affected by hard water in the study area).

2. The dated sample is not closely related to its stratigraphic provenance. The sample was from the surface, was redeposited, or the sample came from wide stratigraphic context.

3. Dated sample were not pretreated properly or did not correspond to other dates from the same stratigraphic context.

Figure 4 notes physiographic features mentioned in the text and Figures 5-9 illustrate the distribution of these dated locations through time. Table 1 (see Appendix) lists the name, date, 1 standard deviation, and reference for each site location.

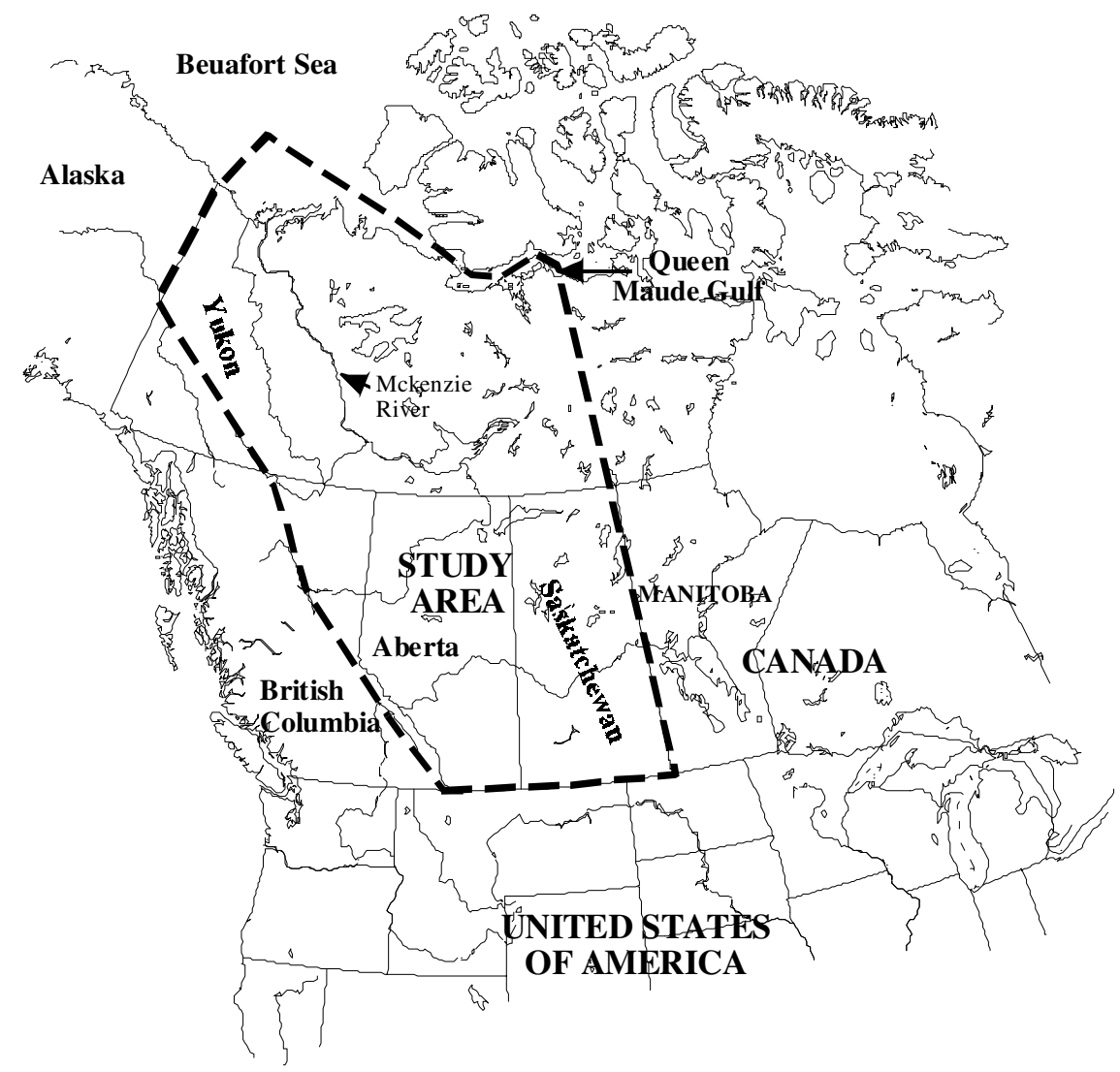

Figure 2 Location of study area

\section{Prelude to Late Wisconsin Maximum}

Prior to the last glacial maximum the study area was devoid of ice as evident by dated plant and animal remains (Vincent 1989:112-3; Hughes et al. 1981:338; Burns1996:108; Burns and Young 1994: 394; Young et al. 1992:1576, 1994:685). As the Mid-Wisconsin drew to a close the Laurentide continental glacier advanced. In the north the glacier advanced west of the Mackenzie River and was 

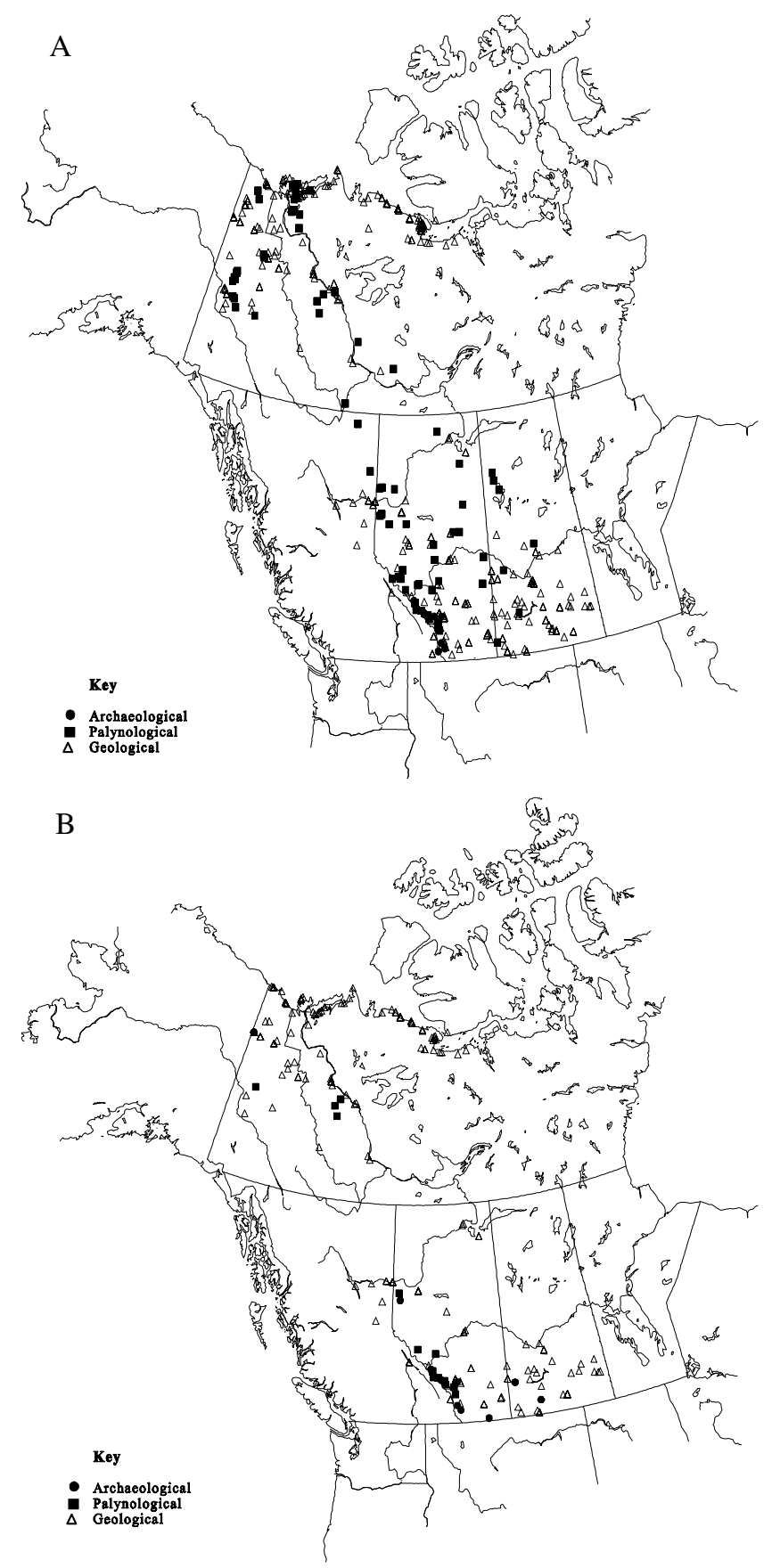

Figure 3 Radiocarbon dated site locations before (A) and after (B) assessment 


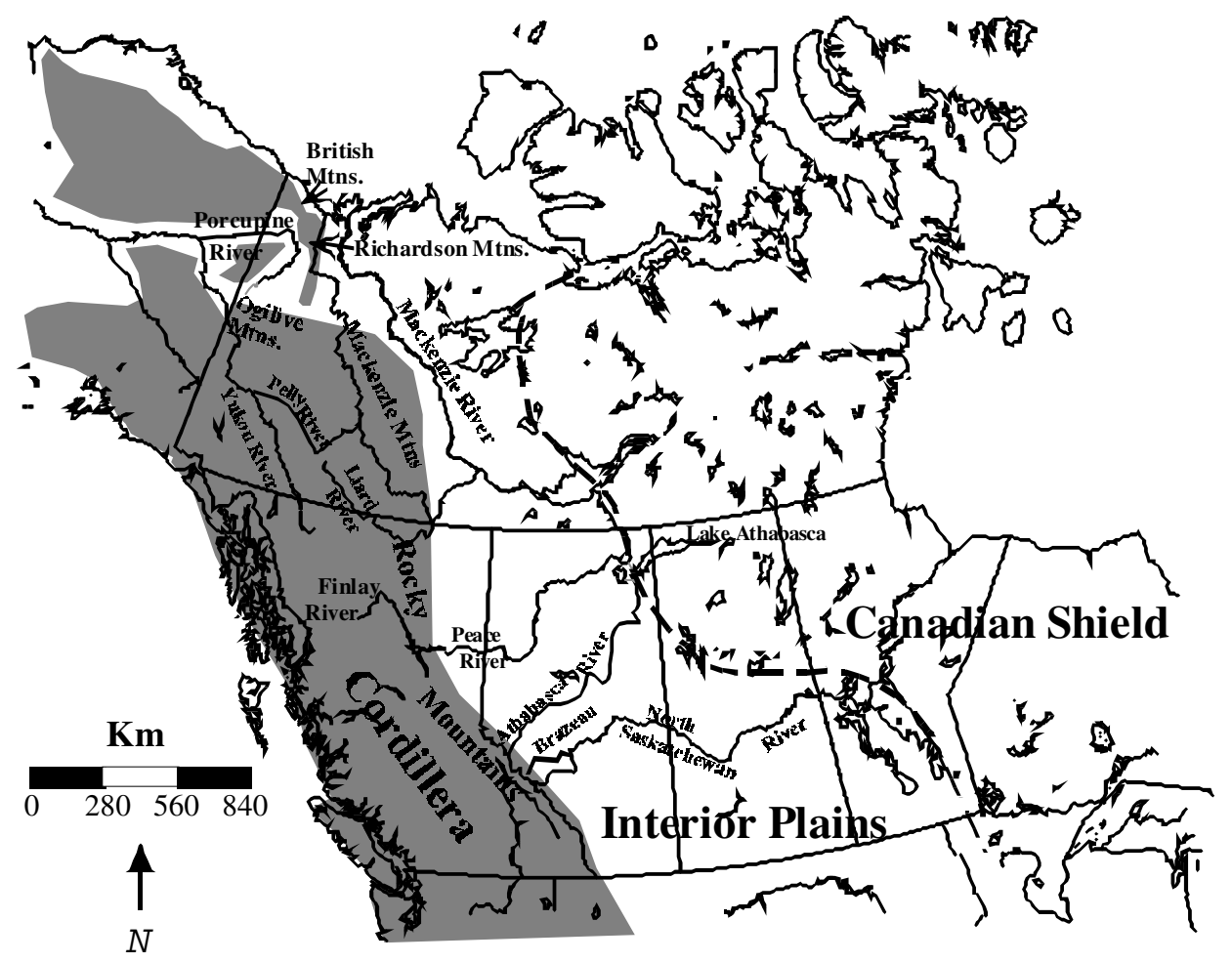

Figure 4 Geographical features of the study areas (after Driver 1998)

blocked by the Richardson and Mackenzie Mountains (see Figure 4 for place names) (Vincent 1989: 129-30; Hughes et al. 1981:329-65). In some instances ice lobes reached $40 \mathrm{~km}$ up some river valleys in the Mackenzie Mountains but it was only during the retreat of the Laurentide ice that some mountain glaciers appear to have coalesced with continental ice (Vincent 1989:130). In the Laird River valley, in southeast Yukon, a date of 23,900 \pm 1140 BP (GSC-2811) from the upper zone of a silt unit was overlain by till indicating that Cordilleran and mountain glaciers advanced through the Laird Plain after this time (Klassen 1987:8; Klassen 1978:1884). No evidence for coalescence between the Laurentide and Montane or Cordilleran glaciers exists on the eastern slopes of the mountains.

Further south in the northern Rocky Mountains of northeastern British Columbia, the sedimentary successions indicate that Late Wisconsin Laurentide ice reached no higher then $950 \mathrm{~m}$ asl in the mountains or foothills in the Peace River district and that it occurred after 22,000 BP (Catto et al. 1996:24-6; Liverman et al. 1989:266-74). Montane glaciers did not reach the eastern slopes of the Rocky Mountains until after the Laurentide began to recede. This was evident by the presence of ${ }^{14} \mathrm{C}$ dates west of the Finlay River of 18,750 120 (TO-709) and 15,180 100 (TO-708) (Catto et al. 1996:23-29; Bobrowsky and Rutter 1992:16-19).

Recent geological research south of the Athabasca River indicated that coalesced glaciers, at the height of the Late Wisconsin, blocked southwestern and central Alberta. Subtill and paleontological studies by Young et al. (1994:683-6, 1999:1567-81) indicated that only Late Wisconsin ice advanced from the north and east and flowed south and west across Alberta up to $1400 \mathrm{~m}$ asl. Levson and Rutter (1996:33-51), citing lithologic, stratigraphic, and morphologic evidence, concluded that 


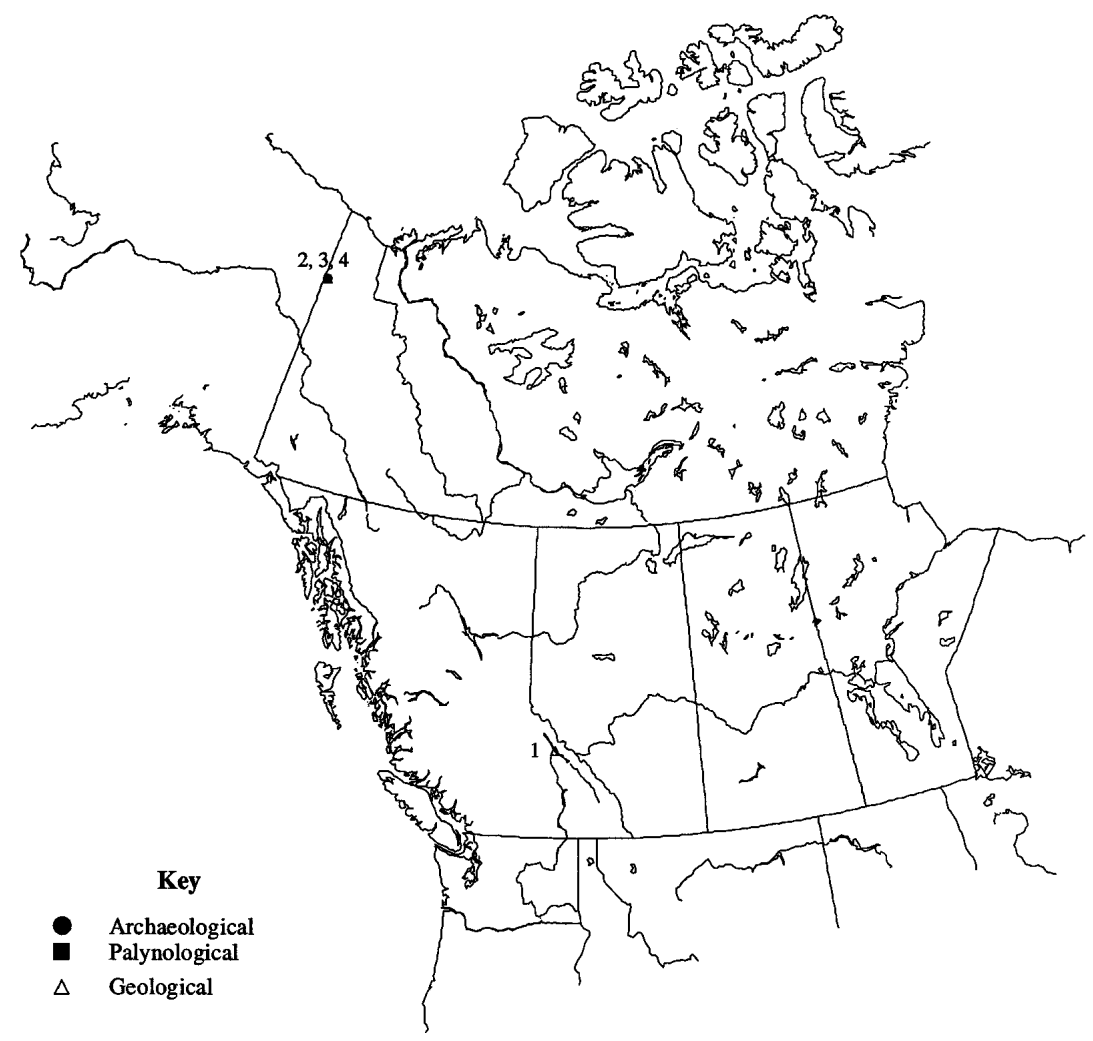

Figure 5 Period 1 site locations, 20,000-17,001 BP

the advancing Laurentide ice coalesced with combined valley and Cordilleran glaciers flowing east out of the Athabasca, Brazeau, and North Saskatchewan river valleys and flowed to the southeast. Since the natural flow out of these valleys was to the northeast, downhill, only the advancing Laurentide ice sheet could have provided the diversion necessary to deflect the east flowing glaciers upslope (Levson and Rutter 1996:44-46, 48) to the south.

\section{Period I: 20,000-17,001 BP}

This time period is represented by only four dates from three sites ranging from 19,650 BP to 17,880 BP (Figure 5). The sites are at opposite ends of the study area and confirm that the height of the glaciation occurred during this time period. The environment was either too severe or the landscape was covered by glaciers to permit plants or animals to survive. The three dates from the two Bluefish Cave sites confirm that eastern Beringia remained unglaciated at the height of glaciation. The lone date from the Rocky Mountain Trench in the south suggests that Cordilleran glaciers reached their maximum extent sometime after 18,500 BP since the sample came from a sand and silt unit that underlay two separate tills (Berry and Dimmie 1982:70).

\section{Period II: 17,000-14,001 BP}

There is an increase in the number of sites during this post-glacial maximum period (Figure 6). Their distribution suggests that deglaciation was occurring simultaneously at either end of the corridor. In the south one dated sample, on badly weathered bone (AECV-681C), appears to be from 


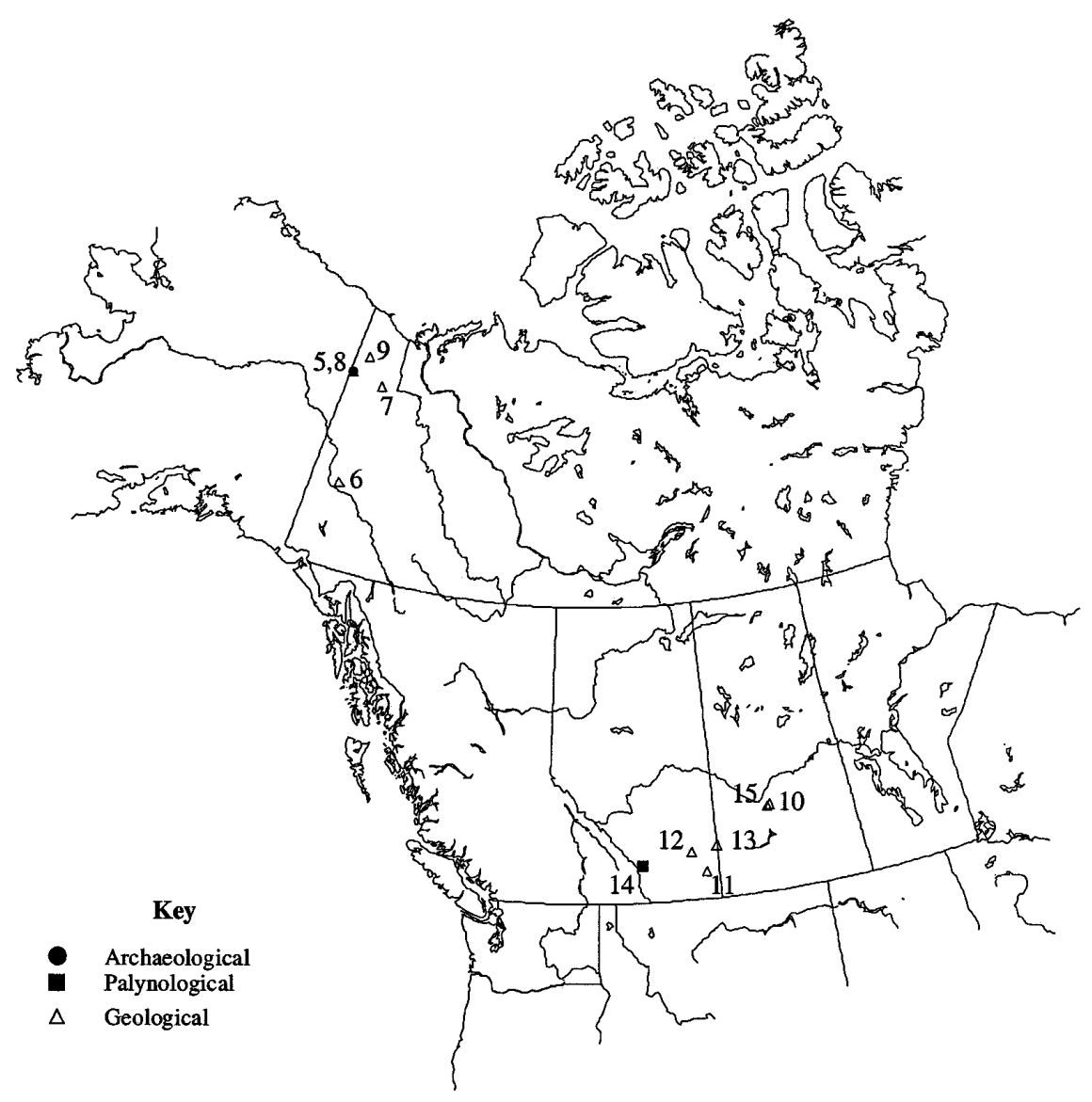

Figure 6 Period 2 site locations, 17,000-14,001 BP

lacustrine sediments overlying bedrock and may represent the earliest glacial lake sediments in the region (Evens 2000:940). Other bone sample dates that have been identified as mammoth (GCS1199 ) and the genus Equus (S-1305) came from possible lacustrine or riverine sands or gravels (Lowdon et al 1975:16; Rutherford et al. 1979:54). The wood sample from the base of the Cartwright Lake core indicates that trees or shrubs were again present in the foothills of the Rocky Mountains. In the north, dated samples indicated the environment supported mammoth (GSC-1893 and GSC-3053) and muskox (RIDDL-557). The latter sample was from a lower loess layer from Bluefish Cave 3 (Cinq-Mars in Morlan 2001) and indicated a dry wind blown environment. Dated wood samples from Old Crow River (GSC-730-2) and the Upper Porcupine River (GSC-2431) indicate trees or shrubs were also present at this time.

\section{Period III: 14,000-11,001 BP}

Fifty-three dated site locations occurred in this time period (Figure 7). As with Period II, the dated site locations occurred in two groups at opposite ends of the study area but the extent of the site distribution has increased. In the north three sub-groups or clusters were indicated along the coast, the Mackenzie River and eastern Beringia (Yukon). The dated samples from the Coastal and Northeastern cluster were all conducted on plant material (wood, grass, moss) except for two marine shell dates from along the eastern coast. With the exception of the marine shells, which came from fine- 
grained marine sediments, the remaining Coastal Cluster dates derive from a variety of geological context including outwash plain, glaciofluvial gravels, and peat deposits. The Northeastern Cluster sample material came mainly from deltaic deposits along the Mackenzie River associated with Glacial Lake Mackenzie (Smith 1992; 1994; Lemmen et al. 1995). The lone exception, Andy Lake (TO2295) (Szeicz et al. 1995), came from a small lake in the Mackenzie Mountains to the west indicating this had become ice-free by this time. The Northwest Cluster sample material included a wider range of material including faunal remains. The latter included horse, mammoth, caribou, moose, mountain sheep, saiga antelope, owl, and bison, which suggested a rich diverse environment in this area. Identified floral samples included willow and possible birch.

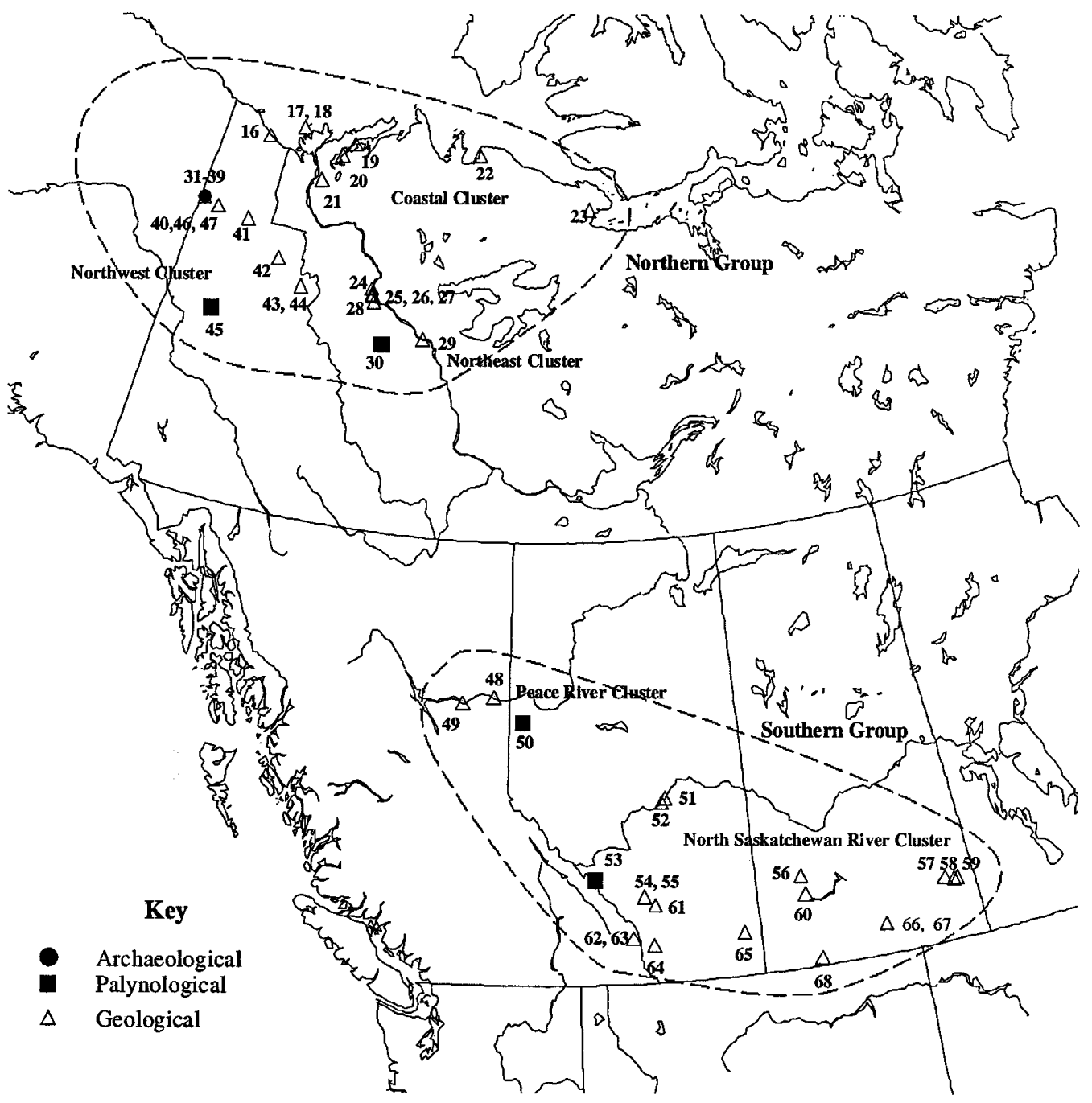

Figure 7 Period 3 site locations, 14,000-11,001 BP 
In the south, the large cluster south of the North Saskatchewan River has grown and sites were present throughout Alberta and Saskatchewan. Dated faunal remains included mammoth, bison, and horse while willow was the only identified floral remain dated. To the northwest of this cluster was the small (3 dated site locations) Peace River Cluster. These two southern clusters appear separated by an area containing no dated site locations. This suggests a second area able to support plants and animals was developing independently of the older and more southern North Saskatchewan Cluster.

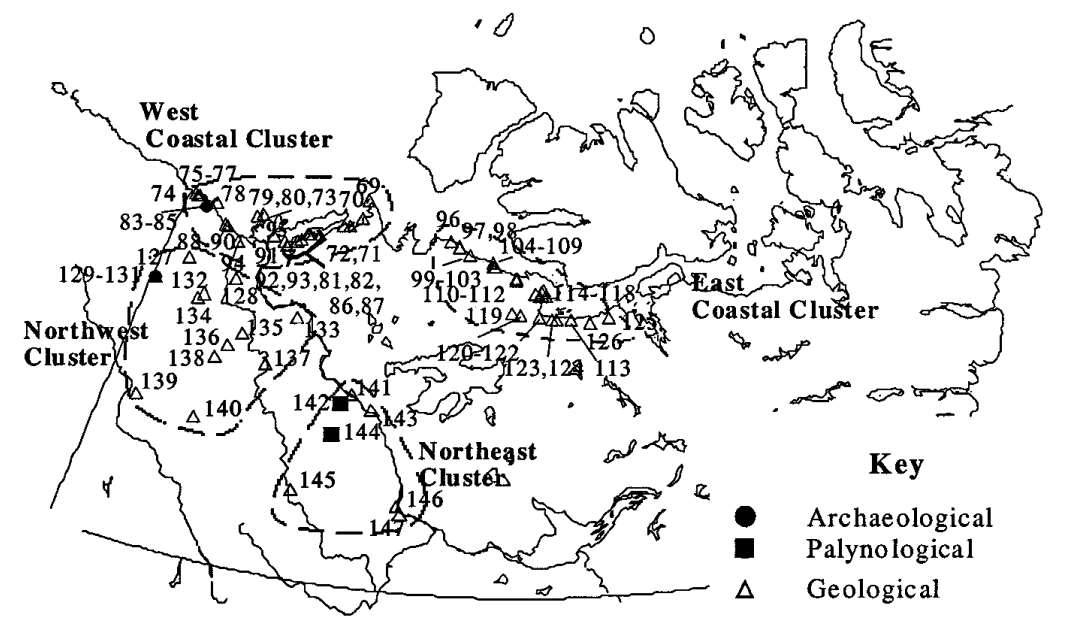

Figure 8 Period 4 northern group site locations, 11,000-8000 BP

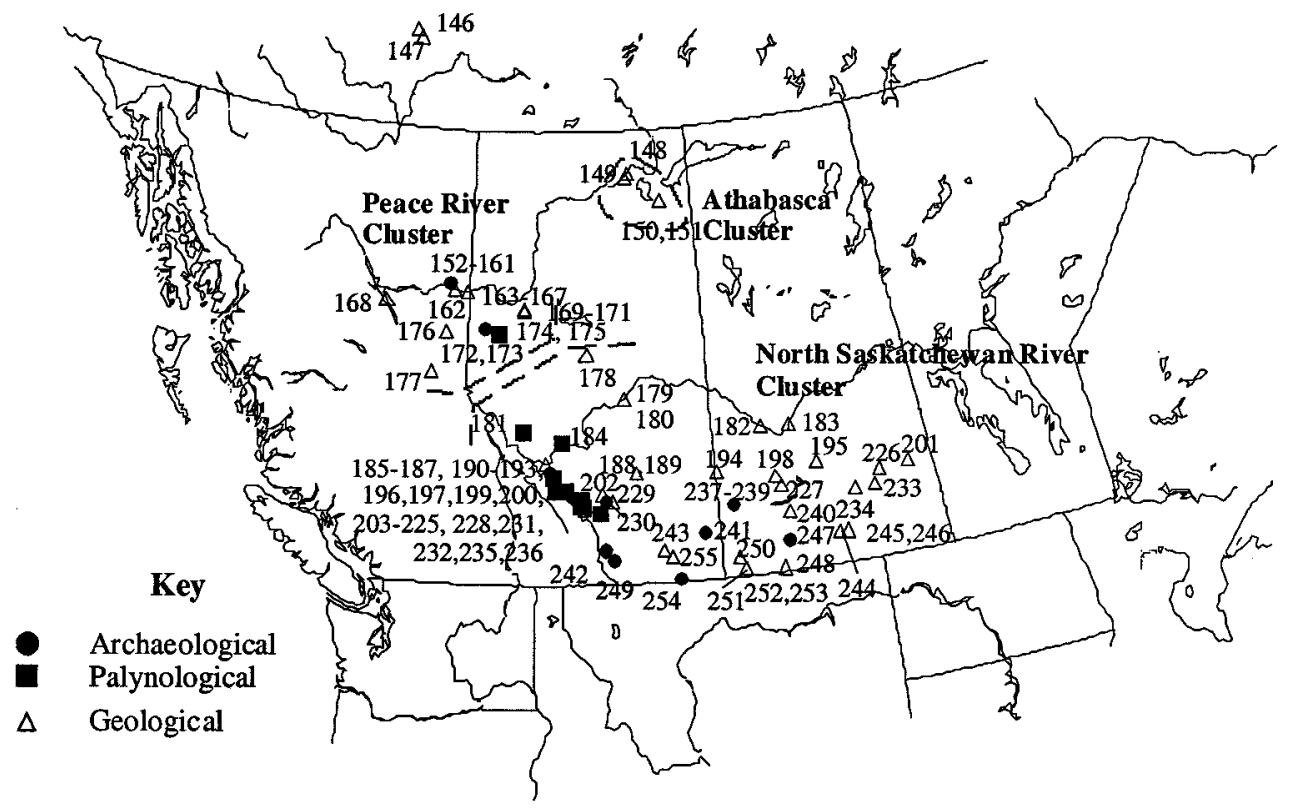

Figure 9 Period 4 southern group site locations, 11,000-8000 BP 


\section{Period 4: 11,000-8000 BP}

One hundred and eighty-seven dated samples from 165 separate site locations were included in this period (Figures 8 and 9). These included 51 archaeological dates (from 16 sites), 115 geological dates (from 102 sites), and 18 palynological dates (from 11 sites). It was during this period that the distribution of dated sites came closest to encompassing the entire length of the ice-free corridor, from the northern coast and Beringian Refugia to the Canada/United States border. Several gaps appeared in this distribution that may reflect a sporadic or patchy colonization process of recently deglaciated landscape. These gaps exist between the Peace Cluster and the Athabasca Cluster and between the Athabasca Cluster and the Northeastern Cluster. The area in between these clusters may not necessarily have been devoid of all plants and animals but were substantially more barren to the point that the preservation of datable material was more unlikely.

\section{DISCUSSION}

I have interpreted these distributions as representing evidence of areas able to support plant and animal life while those areas devoid of dated samples could not. Such an interpretation has been proposed by other researchers (e.g. Burns 1996:107-12; Wilson 1996:97-105). An alternative interpretation could involve a lack of research in areas devoid of dated samples, a lack of exposure of appropriate sediment layers, or a lack of preservation.

Figure 3A should dispel the notion that a lack of research has greatly influenced the distributions. It shows that dated samples have been recovered from throughout the study area. In addition, date lists (e.g. Clague 1980; Jackson and Pawson 1984; Bobrowsky and Rutter 1992:16-17; Lemmen et al. 1995; Liverman et al. 1989; Burns and Young 1994; Burns 1996; Young et al. 1999; Young et al. 1994) that include dates both younger and older than the dates included in this study provide additional evidence that a lack of research is not an acceptable explanation. Similarly, the presence of dated samples from geological contexts older than 20,000 BP indicates that a lack of exposure of appropriate geological sections cannot explain the distribution. Finally, I would argue that the lack of preservation supports the interpretation presented above because the areas lacking dated samples were barren only in the sense that they could not support sufficient plant or animal populations to leave evidence in the geological record, not that they were necessarily devoid of all life (Wilson 1996: 97-105).

Palynology provides support for such an interpretation. In palynology, pollen grains are counted within a specified volume of sediment. For these counts to be statistically meaningful, a minimum number of grains must be counted per volume analyzed (Berglund and Ralska-Jasiewiczowa 1986: 462). This means that layers of sediment that do not reach these minimum counts can be considered barren. I would argue, by rough analogy, that the same is true for geological layers in areas that have not as yet provided dated samples.

I would further argue that if the environment were not productive enough to leave evidence in the geological record than it could not support human populations. Although future research may add new dated sample locations, the most parsimonious explanation of the present evidence indicates that the corridor could not have been used as an early human migration route until after 11,000 BP. This is too late to account for Clovis, which first appears about 11,500 BP (Taylor et al. 1996). Thus, alternative migration routes or time periods must be considered to explain the appearance of Clovis and Folsom at the end of the Pleistocene. 


\section{ACKNOWLEDGMENTS}

This research was conducted as partial fulfillment of my doctoral studies in the Department of Archaeology, Simon Fraser University. Financial support was provided by both the Department of Archaeology and Simon Fraser University. The following professors provided much needed guidance for which I am grateful: Dr K Fladmark, Dr J Driver, and Dr E Nelson.

\section{REFERENCES}

Antevs E. 1934. Climate and early man in North America. American Journal Science 28:304-11.

Apland B, Harington CR. 1994. Pleistocene bison skeleton (Bison bison cf. Occidentalis) from Clayhurst crossing, British Columbia. Geographie physique et Quaternarie 48(2):213-23.

Beaudoin AB. 1991. Alberta radiocarbon dates 19881989, Archaeology in Alberta 1988 and 1989, Archaeological Survey, Provincial Museum of Alberta, Occasional Paper, No. 33

Beaudoin AB, Wright M, Ronaghan B. 1996. Late Quaternary landscape history and archaeology in the 'IceFree Corridor': some recent results from Alberta. Quaternary International 32:113-26.

Beierle B, Smith DG. 1998. Severe drought in the early Holocene (10,000-6800 BP) interpreted from lake sediment cores, southwestern Alberta, Canada Palaeogeography, Palaeoclimatologty, Palaeoecology 140:75-83.

Berglund B, Ralska-Jasiewiczowa M. 1986. Pollen analysis and pollen diagrams. In: Berglund $\mathrm{BE}$, editor Handbook of Holocene palaeoecology and palaeohydrology. London: Wiley \& Sons Ltd. p 455-84.

Berry JC, Drimmie RJ. 1982. University of Waterloo radiocarbon dates I. Radiocarbon 24(1):68-82.

Blake Jr W. 1983. Geological Survey of Canada radiocarbon dates XXIII. Geological Survey of Canada. Paper 83-7.

Blake Jr W. 1984. Geological Survey of Canada radiocarbon dates XXIV. Geological Survey of Canada. Paper 84-7.

Blake Jr W. 1986. Geological Survey of Canada radiocarbon dates XXV. Geological Survey of Canada. Paper $85-7$

Blake W Jr. 1987. Geological Survey of Canada Radiocarbon Dates XXVI. Geological Survey of Canada, Paper 86-7.

Blake W Jr. 1988. Geological Survey of Canada Radiocarbon Dates XXVII. Geological Survey of Canada, Paper 87-7.

Bryan AL. 1969. Early man in America and the Late Pleistocene chronology of western Canada and Alaska. Current Anthropology 10(4):339-65.

Bobrowsky P, Rutter NW. 1992. The Quaternary geologic history of the Canadian Rocky Mountains. Geographie physique et Quaternaire 46(1):5-50.

Burns JA. 1986. A 9000-year-old Wapiti (Cervus elaphus) skeleton from northern Alberta, and its implica- tions for the Early Holocene Environment. Géographie physique et Quaternaire Vol. XL(1):105-8.

Burns JA. 1996. Vertebrate paleontology and the alleged Ice-Free Corridor: the meat of the matter. Quaternary International 32:107-12.

Burns JA, Young RR. 1994. Pleistocene mammals of the Edmonton area, Alberta. Part I. The carnivores. Canadian Journal of Earth Sciences 31:393-400.

Catto N, Liverman DGE, Bobrowsky P, Rutter N. 1996. Laurentide, cordilleran, and montane glaciation in the western Peace River - Grande Prairie Region, Alberta and British Columbia, Canada. Quaternary International 32:21-32.

Christiansen EA. 1979. The Wisconsinan deglaciation of southern Saskatchewan and adjacent areas. Canadian Journal of Earth Sciences 16:913-38.

Christiansen EA. 1983. The Denholm landslide, Saskatchewan, Part I: Geology. Canadian Geotechnical Journal 20:197-207.

Christiansen ES, Sauer EK. 1988. Age of the Frenchman Valley and associated drift south of the Cypress Hills, Saskatchewan, Canada. Canadian Journal of Earth Sciences 25:1703-8.

Cinq-Mars J. 1979. Bluefish Cave I: a Late Pleistocene eastern Beringian cave deposit in the northern Yukon. Canadian Journal of Archaeology 3:1-32.

Cinq-Mars J, Harington CR, Nelson DE, MacNeish RS. 1991. Engigstciak revisted: a note on early Holocene AMS dates from the Buffalo Pit. In: NOGAP Archaeological Project: an integrated archaeological research and management approach. Canadian Archaeological Association, Occasional Paper No. 1.

Clague JJ. 1980. Late Quaternary geology and geochronology of British Columbia: Part 1: radiocarbon dates. Geological Survey of Canada, Paper 80-13

Driver JC. 1998. Human adaptation at the Pleistocene/ Holocene boundary in western Canada, 11,000 to 9000 BP. Quaternary International 49/50:141-50.

Driver JC, Handly M, Fladmark KR, Nelson DE, Sullivan GM, Preston R. 1996. Stratigraphy, radiocarbon dating and culture history of Charlie Lake Cave, British Columbia. Arctic 49(3):265-77.

Dyck W, Fyles JG. 1962. Geological Survey of Canada radiocarbon dates I. Radiocarbon 4:13-26.

Dyck W, Fyles JG. 1963. Geological Survey of Canada radiocarbon dates II. Radiocarbon 5:39-55.

Dyck W, Fyles JG. 1964. Geological Survey of Canada radiocarbon dates III. Radiocarbon 6:167-81. 
Dyck W, Lowdon JA, Fyles JG, Blake W Jr. 1966. Geological Survey of Canada radiocarbon dates V. Radiocarbon 8:96-127.

Evans DJA. 2000. Quaternary geology and geomorphology of the Dinosaur Provincial Park area and surrounding plains, Alberta, Canada: the identificaiton of former glacial lobes, drainage diversions and meltwater flood tracks. Quaternary Science Reviews 19:93158.

Evans DJA, Campbell IA. 1992. Glacial and Postglacial stratigraphy of Dinosaur Provincial Park and surrounding plains, southern Alberta, Canada. Quaternary Science Reviews 11:535-55.

Fladmark KR. 1979. Routes: alternative migration corridors for early man in North America. American Antiquity 44(1):55-69.

Fladmark KR, Driver JC, Alexander D. 1988. The Paleoindian component at Charlie Lake Cave (HbRf-39). British Columbia American Antiquity 53(2):371-84.

Harington CR, Cinq Mars J. 1995. Radiocarbon dates on Saiga Antelope (Saiga tatarica) fossils from Yukon and the Northwest Territories. Arctic 48(1):1-7.

Harrison JE. 1976. Dated organic material below Mazama (?) tephra: Elk Valley, British Columbia. Geological Survey of Canada, Paper 76-1C

Head T. 1999. Report of radiocarbon dating analysis from BETA Analytic. Copy provided by T Head, Bison Historical Services, Calgary, Alberta.

Hickman M, Schweger CE. 1996. The Late Quaternary palaeoenvironmental history of a presently deep freshwater lake in east-central Alberta, Canada and palaeoclimate implications. Palaeogeography, Palaeoclimatology, Palaeoecology 123:161-78.

Hickman M, Schweger CE, Habgood T. 1984. Lake Wabamun, Alta.: a paleoenvironmental study. Canadian Journal of Botany 62:1438-65.

Holloway RG Bryant VM Jr, Valastro S. 1981. A 16,000 year pollen record from Lake Wabamun, Alberta, Canada. Palynology 5:195-208.

Hughes OL, Harington CR, Janssens, JA, Matthews, JV, Morlan, RE, Rutter NW, Schweger CE. 1981. Upper Pleistoncene stratigraphy, paleoecology, and archaeology of the northern Yukon interior, eastern Beringia 1. Bonnet Plume Basin. Arctic 34(4):329-65.

Jackson LE, Pawson M. 1984. Alberta radiocarbon dates: listings of radiocarbon dates with regional significance to the Late Quaternary geochronology and geomorphology of Alberta. Geological Survey of Canada, Paper 83-25.

Jackson LE Jr. 1983. Comments on chronology of Late Wisconsinan glaciation in middle North America. Quaternary Science Review 1:vii-xiv.

Johnson WA. 1933. Quaternary geology of North America in relation to the migration of man. In Jenness $D$, editor. The American Aborigines. Toronto: University of Toronto Press. p 11-45.

Klassen RW. 1978. A unique stratigraphic record of the late Tertiary-Quaternary events in southeastern Yukon. Canadian Journal of Earth Sciences 15:18846.

Klassen RW. 1987. The Tertiary Pleistocene stratigraphy of the Laird Plain, Southeastern Yukon Territory. Geological Survey of Canada, Paper 86-17.

Lemmen DS, Duk-Rodkin A, Bednarski JM. 1995. Late glacial drainage systems along the northwestern margin of the Laurentide Ice Sheet. Quaternary Science Reviews 13:805-28.

Levson VM, Rutter NW. 1996. Evidence of cordilleran Late Wisconsinan glaciers in the 'Ice-Free Corridor'. Quaternary International 32:33-51.

Liverman DGE, Catto NR, Rutter NW. 1989. Laurentide Glaciation in west-central Alberta: a single (Late Wisconsinan) event. Canadian Journal of Earth Sciences 26:266-74.

Lowdon JA, Blake W Jr. 1968. Geological Survey of Canada radiocarbon dates VII. Radiocarbon 10:20745.

Lowdon JA, Blake W Jr. 1970. Geological Survey of Canada radiocarbon dates IX. Radiocarbon 12:46-86.

Lowdon JA, Blake W Jr. 1973. Geological Survey of Canada radiocarbon dates XIII. Geological Survey of Canada, Paper 73-7.

Lowdon JA, Blake W Jr. 1975. Geological Survey of Canada radiocarbon dates XV. Geological Survey of Canada, Paper 75-7.

Lowdon JA, Blake W Jr. 1976. Geological Survey of Canada radiocarbon dates XVI. Geological Survey of Canada, Paper 76-7.

Lowdon JA, Blake W Jr. 1977. Geological Survey of Canada radiocarbon dates XVII. Geological Survey of Canada, Paper 77-7.

Lowdon JA, Blake W Jr. 1978. Geological Survey of Canada radiocarbon dates XVIII. Geological Survey of Canada, Paper 78-7.

Lowdon JA, Blake W Jr. 1979. Geological Survey of Canada radiocarbon dates XIX. Geological Survey of Canada, Paper 79-7.

Lowdon JA, Blake W Jr. 1980. Geological Survey of Canada radiocarbon dates XX. Geological Survey of Canada, Paper 80-7.

Lowdon JA, Fyles JG, Blake W Jr. 1967. Geological Survey of Canada radiocarbon dates VI. Radiocarbon 9: 167-8.

Lowdon JA, Robertson IM, Blake W Jr. 1971. Geological Survey of Canada radiocarbon dates XI. Radiocarbon 13:255-324.

MacDonald GM, Beukens RP, Kieser WE. 1991. Radiocarbon dating of limnic sediments: a comparative analysis and discussion. Ecology 72(3):1150-5.

Mandryk CS. 1992. Paleoecology as contextual archaeology: human viability of the Late Quaternary ice-free corridor, Alberta, Canada. Unpublished PhD dissertation. University of Alberta, Edmonton.

Mandryk CS. 1996. Late Wisconsinan deglaciation of 
Alberta: processes and paleogeography. Quaternary International 32:79-85.

Mandryk CS, Rutter N. 1996. The Ice-Free Corridor revisted. In: Mandryk CS, Rutter N, guest editors. Quaternary International 32.

Mathews WH. 1980. Retreat of the last ice-sheets in northeastern British Columbia and adjacent Alberta. Geological Survey of Canada. Bulletin 331

McCallum KJ, Dyck W. 1960. University of Saskatchewan radiocarbon dates II. American Journal of Science, Radiocarbon Supplement 2:73-81.

McCallum KJ, Wittenberg J. 1962. University of Saskatchewan radiocarbon dates III. Radiocarbon 4: 71-80.

McCallum KJ, Wittenberg J. 1965. University of Saskatchewan radiocarbon dates IV. Radiocarbon 7: 229-35.

McCallum KJ, Wittenberg J. 1968. University of Saskatchewan radiocarbon dates V. Radiocarbon 10 374-5.

McNeely R. 1989. Geological Survey of Canada radiocarbon dates XXVIII. Geological Survey of Canada, Paper 88-7.

McNeely, R. and McCuaig, S. 1991. Geological Survey of Canada radiocarbon dates XXIX. Geological Survey of Canada, Paper 89-7.

McNeely, R. and Jorgensen, PK. 1992. Geological Survey of Canada radiocarbon dates XXX. Geological Survey of Canada, Paper 90-7.

Meltzer DJ. 1993. Pleistocene peopling of the Americas. Evolutionary Anthropology 1(5):157-69.

Meyer D, Liboiron H. 1990. A Paleoindian drill from the Niska site in southern Saskatchewan. Plains Anthropologists 35(129):299-302.

Morlan RE. 1980. Taphonomy and archaeology in the Upper Pleistocene of the northern Yukon Territory: a glimpse of the peopling of the New World. National Museum of Man, Archaeological Survey of Canada. Mercury Series Paper No. 94.

Morlan RE. 2001. Canadian Archaeological Radiocarbon Database. Complied by Richard E Morlan. Database programming and design by Pictographics Ltd.

Nelson DE. 1998. Radiocarbon dating definitions and their consequences. Isotope Lab Internal Report.

Rains B, Welch J. 1988. Out-of-phase Holocene terraces in part of the North Saskatchewan river basin, Alberta. Canadian Journal of Earth Sciences 25:454-64.

Reasoner MA, Hickman M. 1989. Late Quaternary Environmental change in the Lake O'Hara Region, Yoho National Park, British Columbia. Palaeogeography, Palaeoclimatology, Palaeoecology 72:291-316.

Reasoner MA, Osborn G, Rutter NW. 1994. Age of the Crowfoot advance in the Canadian Rocky Mountains: a glacial event coeval with the Younger Dryas oscillation. Geology 22:439-42.

Reeves BOK. 1973. The nature and age of the contact between the laurentide and cordilleran ice-sheets in the western interior of North America. Arctic and Alpine Research 5(1):1-16.

Reeves BOK, Dormaar JF. 1972. A partial holocene pedological and archaeological record from the southern Alberta Rocky Mountains. Arctic and Alpine Research 4(4):325-36

Ronaghan B. 1993. The James Pass project: early Holocene occupation in the front ranges of the Rocky Mountains. Canadian Journal of Archaeology 17:8591.

Rutherford AA, Wittenberg J, Wilmeth R. 1979. University of Saskatchewn radiocarbon dates VIII. Radiocarbon 21(1):48-94.

Rutter NW. 1980. Late Pleistocene history of the western Canadain Ice-Free Corridor. Canadian Journal of Anthropology 1:1-7.

Schweger CE, Hickman M. 1989. Holocene paleohydrology of central Alberta: testing the general-circulationmodel climate simulations. Canadian Journal of Earth Sciences 26:1826-33.

Schweger CE. 1989. Paleoecology of the western Canadian Ice-Free Corridor. In: Fulton RJ,e ditor. Quaternary geology of Canada and Greenland. Ottawa: Geological Survey of Canada.

Shackleton DM, Hills LV. 1977. Post-glacial ungulates (Cervus and Bison) from Three Hills, Alberta. Canadian Journal of Earth Sciences 14:963-86.

Smith DG. 1992. Glacial Lake Mackenzie, Mackenzie Valley, Northwest Territories, Canada. Canadian Journal of Earth Sciences 29:1756-66.

Smith DG. 1994. Glacial Lake McConnell: paleogeography, age, duration, and associated river deltas, $\mathrm{McK}$ enzie River Basin, Western Canada. Quaternary Science Review 13:829-43.

Stuiver M, Polach H. 1977. Reporting on ${ }^{14} \mathrm{C}$ data. $R a$ diocarbon 19(3):355-63.

Szeicz JM, MacDonald GM, Duk-Rodkin A. 1995. Late Quaternary vegetation history of the central Mackenzie Mountains, Northwest Territories, Canada. Palaeogeography, Palaeoclimatology, Palaeoecology 113:351-71.

Taylor RE, Haynes CV Jr, Stuiver M. 1996. Clovis and Folsom age estimates: stratigraphic context and radiocarbon calibrations. Antiquity 70(269):515-25.

Van Dyke S. 1994. Oldman River Dam Prehistoric Archaeology Mitigation Program technical series no. 1: campsites study. Archaeological Survey of Alberta, Manuscript Series, Alberta Culture, Provincial Museum of Alberta.

Vincent JS. 1989. Quaternary geology of the northern Canadian Interior Plains. In: Fulton RJ, editor. Quaternary geology of Canada and Greenland. Geological Survey of Canada, No. 1. p 100-37.

Walton A, Trautman MA, Friend JP. 1961. Isotopes, Inc. radiocarbon measurements I. Radiocarbon 3:47-59.

White JM, Osborn G. 1992. Evidence for a Mazama-like tephra deposited ca. 10,000 BP at Copper Lake, Banff 
National Park, Alberta. Canadian Journal of Earth Sciences 29:52-62.

White JM, Mathewes RW. 1986. Postglacial vegetation and climatic change in the upper Peace River District, Alberta. Canadian Journal of Botany 64:2305-18.

Wilson MC. 1996. Late Quaternary vertebrates and the opening of the Ice-Free Corridor, with special reference to the genus bison. Quaternary International 32: 97-105.

Wilson M, Churcher CS. 1978. Late Pleistocene cameloops from the Gallelli Pit, Calgary, Alberta: Morphology and geologic setting. Canadian Journal of Earth Sciences 15(5):729-40.
Woolf K. 1993. Radiocarbon chronology for glacial Lake Peace. Unpublished MS thesis. Department of Geography, Simon Fraser University.

Young RR, Burns JA, Rains RB, Chowalter DB. 1999. Late Pleistoncene glacial geomorphology and environment of the Hand Hills region and southern Alberta, related to Middle Wisconsin fossil prairie dog sites. Canadian Journal of Earth Sciences 36:156781.

Young RR, Burns JA, Smith DG, Arnold LD, Rains RB. 1994. A single Late Wisconsin Laurentide glaciation, Edmonton area and southwestern Alberta. Geology $22: 683-6$. 


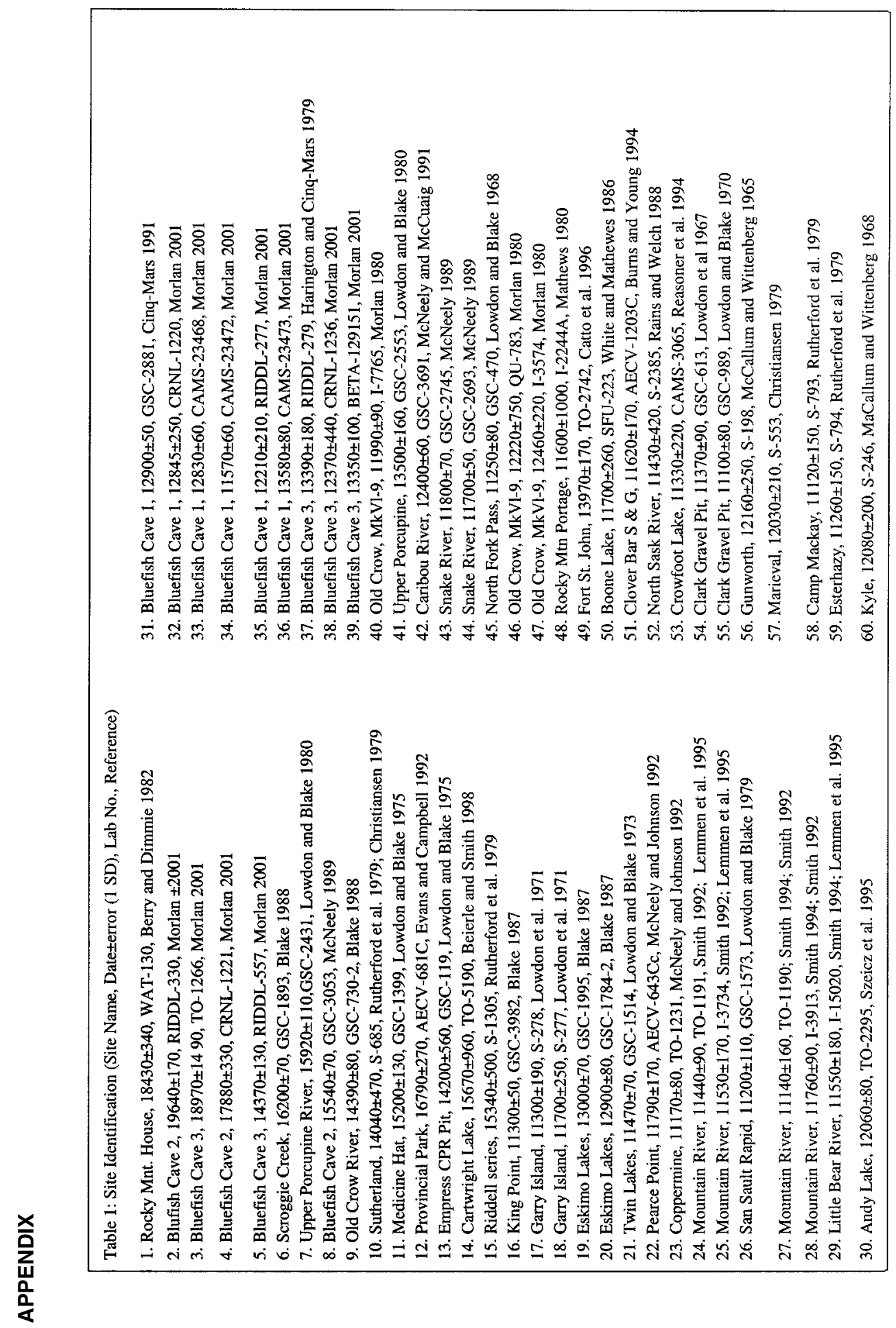




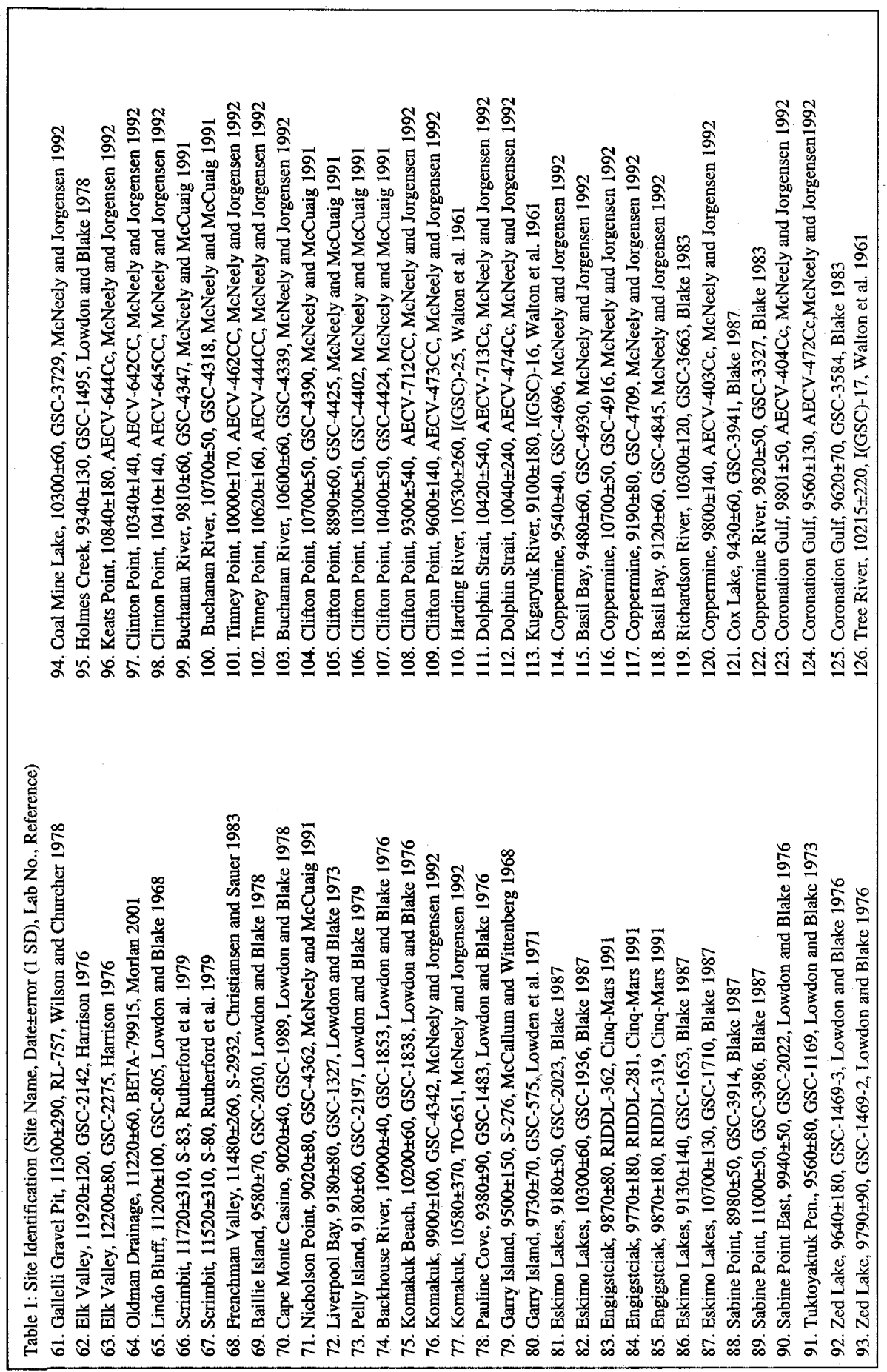




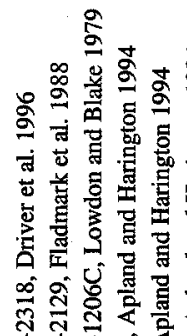

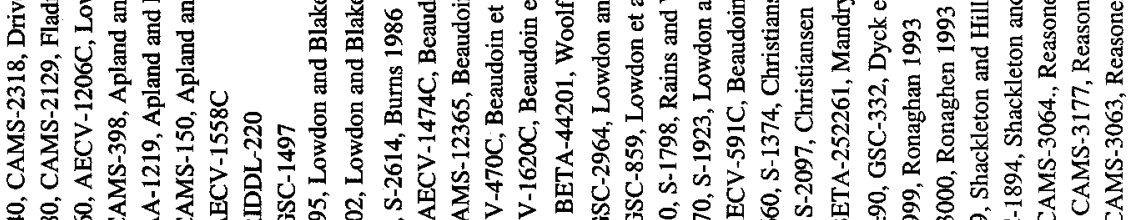
की

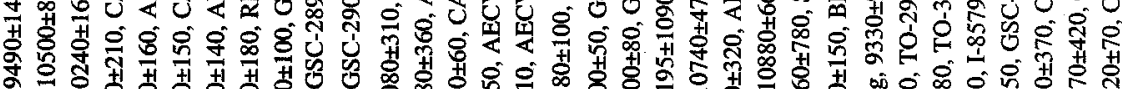

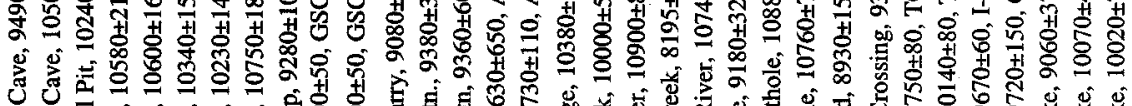

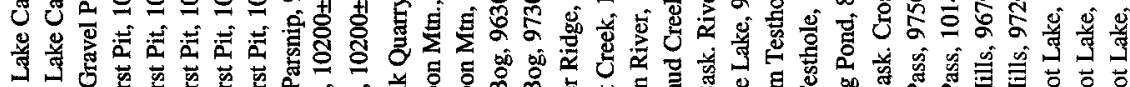
o.

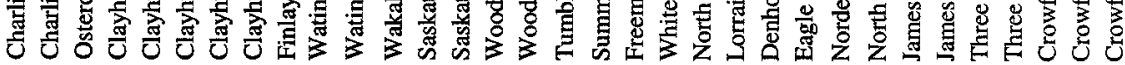

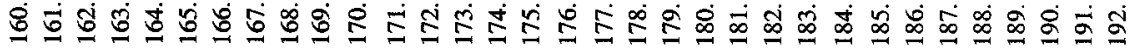

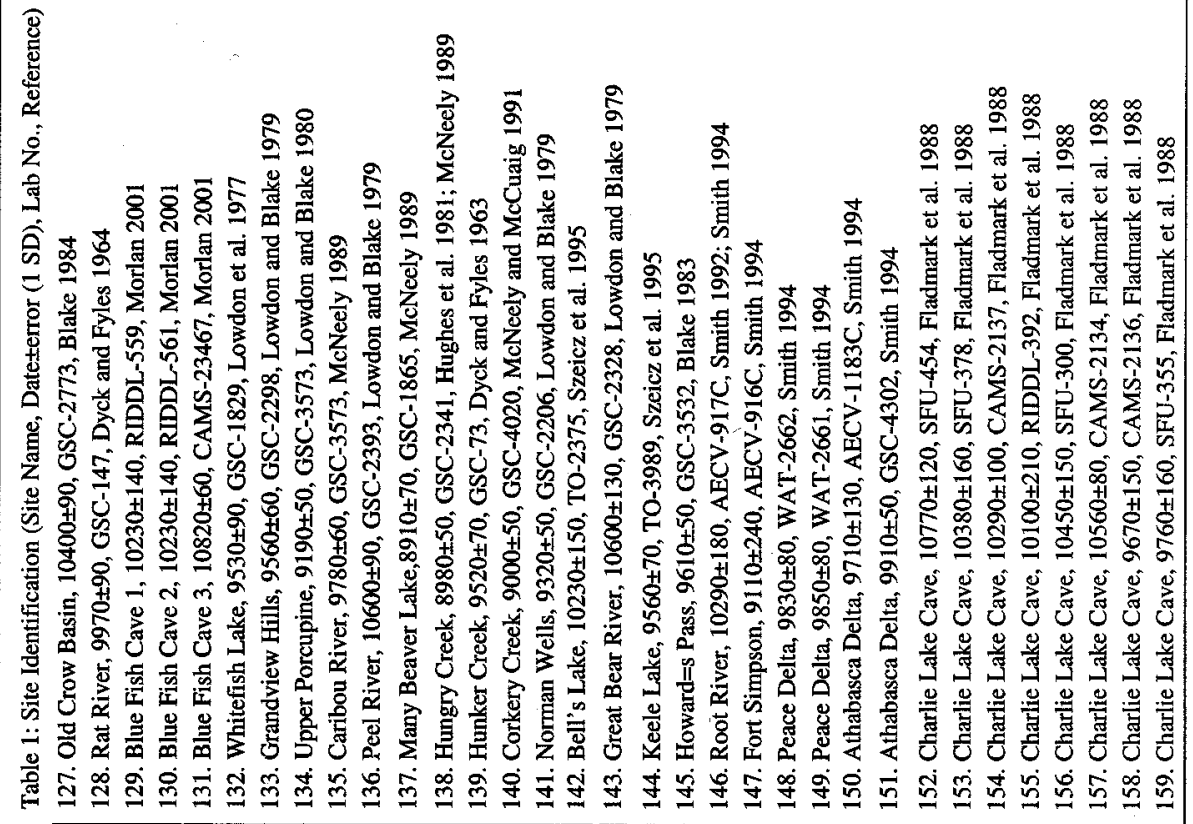



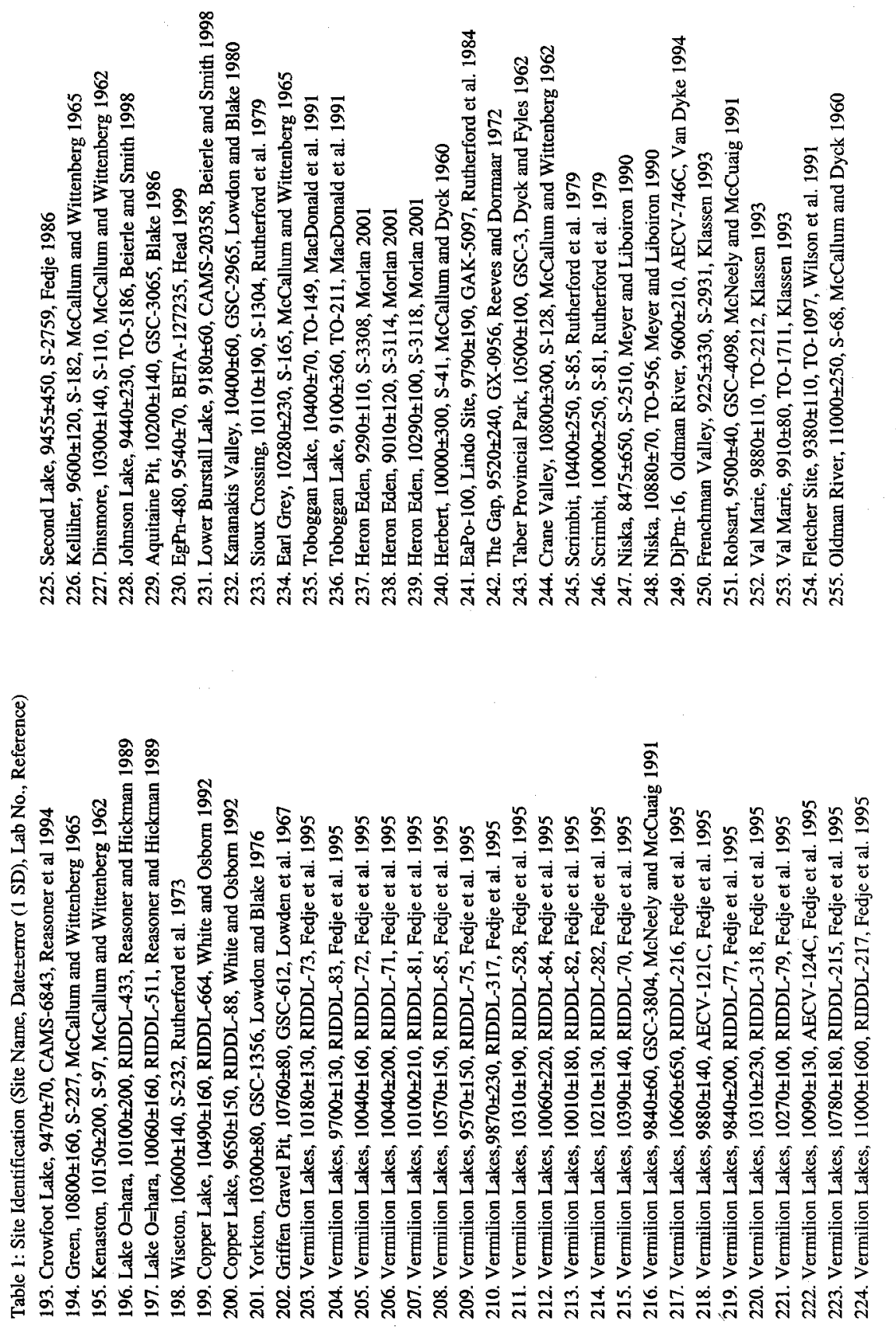